\title{
Identification of tumor-associated antigens in human thyroid papillar carcinoma
}

\author{
N. V. Rodnin ${ }^{1}$, I. O. Tykhonkova ${ }^{1}$, R. G. Kyyamova', O. M. Garifulin ${ }^{1}$, I. T. Gout ${ }^{1,2}$, \\ V. V. Filonenko'

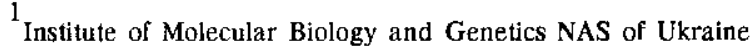 \\ 150 vul. Acad. Zabolotnoho, Kyiv 03143, Ukraine \\ 2 \\ ${ }^{2}$ Ludwig Institute for Cancer Research \\ 91 Riding House Street, London WIW 7BT, UK
}

\begin{abstract}
In this study two $C D N A$ expressing libraries generated from thyroid papillar carcinomas were screened using SEREX approach. Thirty positive cDNA clones representing seventeen different genes were identified from both libraries. It is important to note, that three of them were isolated previously by other laboratories in SEREX screens of various types of human cancer. These include transcription factor NZF, $\alpha$-catenin and BAC RPII-a protein with unknown function. Moreover, we identified a whole panel of novel potential tumor-associated antigens, which would be further investigated. We are particularly interested in more detailed analysis of cathepsin $H$ and transducer of ErbB2 (TOB2), which are differentially expressed in various types of human cancer. We will analyse the frequency of autoantibodies against identified antigens in sera of patients with various malignancies and healthy donors by heterologous screening. It is expected that among the clones isolated in this study, there might be novel cancer-associated markers.
\end{abstract}

Introduction. Thyroid cancer, although the most frequent malignancy of the endocrine system, is in general a rare disease. It accounts for about $1 \%$ of all human cancers, with a higher prevalence in women $(5-9$ of 100000$)$ as compared with men $(2-4$ of 100000) [1]. Normally, thyroid cancer is a disease with good prognosis, but about $30 \%$ of tumors dedifferentiate and may finally develop into highly malignant anaplastic thyroid carcinomas with the mean survival time of less than 8 months. The thyroid gland is highly sensitive to radiation-induced oncogenesis. This is verified by numerous reports from survivors after Hiroshima and Nagasaki, the Nevada, Novaya Zemlya and Marshal Island atomic bomb tests [2]. Investigations provided after Chernobyl nuclear plant accident have shown the increase of thyroid cancer two fold in adults and three fold in children.

The success of cancer therapy depends on the stage of the disease detection. Today, the specific markers for early detection of thyroid cancer are

C) N. V. RODNIN, 1. O. TYKHONKOYA, R. G. KYYAMOYA, o. M. GARIFULLIN, I. T. GOUT. V. V. FILONENKO, 2003 unknown and the search for them is a problem of outstanding value.

At present, several methods for the search of tumor-associated antigens exist, such as DNA Microarrays, SAGE, CNAPS, SEREX (Serological analysis of recombinant cDNA expressing libraries) with their advantages and deficiencies [3]. SEREX method is based on the study of cancer patient's immune response. Samples of cancer tissue are used for the creation of expressing cDNA libraries further screened by autologous sera. This method is suitable for the identification of the proteins (or their immunogenic epitopes) that cause immune responses in cancer patients.

SEREX method has been successfully applied for the detection of tumor-associated antigens from various types of human cancer, including breast, colorectal, renal etc. [4-6].

These studies led to the identification of several novel antigens, which are currently used as markers of malignant transformation and for the production of anti-cancer vaccines [7]. We have previously reported 
the identification of 15 immunoreactive clones isolated by SEREX screening of thyroid cancer cDNA expressing libraries $[8]$. We have extended the search for novel antigens by generating and screening of two novel libraries from thyroid papillar cancer. Here, we report the identification of further $\mathbf{3 0}$ immunoreactive clones, representing 17 genes. It is important to note that three from identified genes have been previously found by SEREX approach from other types of human cancer. Heterologous screens of isolated clones with a panel of sera from healthy donors and patients with various types of cancer is currently in progress.

Materials and Methods. The samples of human thyroid papillar carcinomas and autologous sera were kindly provided by Dr. V. Usenko and Dr. V. Lysogubov (BIONTEC, Ukraine).

Purification of total and messenger RNA. Total RNA was purified from freshly frozen in liquid nitrogen tumor samples by the modified guanidineisothiocyanate method [9]. mRNA was isolated by affinity chromatography using oligo(dT) Dynabeds matrix («Dynal», UK). The quality and quantity of the preparations obtained were estimated by spectrophotometrical methods and by the electrophoresis in $1 \%$ formaldehyde-agarose gels. The mRNA preparations were stored under ethanol at $-80{ }^{\circ} \mathrm{C}$ until further use.

Generation of $c D N A$ expressing libraries. Five micrograms of purified mRNA preparations were applied for cDNA synthesis with the use of cDNA synthesizing kit («Stratagene», USA). The oligonucleotide primer containing $X h o l$ site and an oligo(dT) tail was used for the initiation of reverse transcription. The effectiveness of the synthesis was estimated with the use of the test RNA preparation from Stratagene kit followed by electrophoresis in $1 \%$ agarose gels.

cDNA fragments accounting $0.5-3 \mathrm{~kb}$ were extracted from the gels using DNA extraction kit («Qiagen», USA). The fragments obtained were cloned into bacteriophage $\lambda$ DNA (UniZap vector) by $X h o I$ and EcoRI restriction sites. The phagemide obtained was packed into phage particles with the use of Gigapack Gold III kit («Stratagene», USA). For the estimation of primary libraries titers Escherichia coli $\mathrm{XL}-1$ Blue $\mathrm{MRF}^{\prime}$ cells were infected by recombinant phages in appropriate dilutions. The percentage of non-recombinant phages was detected by blue/white plaque selection in the presence of IPTG and X-Gal ( Sigma», USA).

Affinity purification of the sera. Sera samples from patients with thyroid cancer were diluted 1:1 with glycerol and stored at $-20{ }^{\circ} \mathrm{C}$ until further use. For the affinity purification, prepared sera samples were diluted 1:10 by TBS ( $10 \mathrm{mM}$ Tris- $\mathrm{HCl}, \mathrm{pH} 8.0$, $150 \mathrm{mM} \mathrm{NaCl}$ ) and incubated with affinity matrixes containing covalently crosslinked $E$, coli and $\lambda$ phage proteins (Y1090 and BNN97 matrixes respectively). This technique allowed the elimination of serum immunoglobulins directed against bacterial and phage proteins. The depleted sera were further diluted by TBS $1: 100$ and stored at $4{ }^{\circ} \mathrm{C}$ with the addition of $0.02 \% \mathrm{NaN}_{3}$.

Immunoscreening of $c D N A$ expression libraries. For the primary screening $600 \mu 1$ of E. coli XL-1 Blue MRF' cells were infected with $6 \cdot 10^{3}$ phage particles and plated onto $150 \mathrm{~mm}$ Petri dishes. The expression of recombinant proteins was induced by the addition of $1 \mathrm{mM}$ IPTG for 5-7 hours. The transfer of the proteins to the nitrocellulose membrane Hybond-C was carried out overnight by standard method.

The identification of IgG expressing clones was performed by immunoblotting of filters with antihuman horse radish peroxidase conjugate (dilution 1:2000, «Sigma», USA). Detection of primary positives was carried out by probing filters with the autologous sera and anti-human alkaline phosphatase conjugate staining. Positive clones were extracted from the agar and stored in $0.5 \mathrm{ml}$ of SM buffer with the addition of $20 \mu \mathrm{l}$ of chloroform.

The secondary screening of isolated clones was performed on $90 \mathrm{~mm}$ Petri dishes by the same method. Plasmid DNA from positive clones was obtained by in vivo recombination in $E$. coli strain XL-1 Blue MRF'.

Restriction analysis and sequencing of isolated clones. The size of cDNA insertions was detected by restriction analysis with EcoRI and $\mathrm{XhOI}$ endonucleases followed by $1 \%$ agarose gel electrophoresis. Sequencing of the inserts was performed by a standard protocol using the automatic sequencer ABI 373 (Applied Biosystem). The identification of positive clones and their analysis was performed with a help of EMBO, GenBank, dBest and SEREX databases.

Results and Discussion. Taking into consideration the increase of thyroid cancer frequency and the absence of specific markers for early diagnostic purposes we have extended our search for thyroid cancer associated markers. In this study, we have used SEREX methodology aimed on the identification of tumor-associated proteins which induce immune response in cancer patients. We have successfully applied SEREX technique in previous studies, which 
led us to the identification of 25 immunoreactive clones from thyroid cancer and melanoma [8, 10].

In order to extend the search for novel antigens, we have created two additional cDNA expressing libraries from thyroid papillar carcinomas with the titer of 1.05 and $1.4 \cdot 10^{6}$ respectively. The percentage of non-recombinant phages was less than $1 \%$ for both libraries. These tests indicated that both libraries are suitable for immunoscreening by SEREX methodology.

The primary immunoscreening with autologous sera allowed us to isolate 170 primary positives clones, which showed various degree of immunoreactivity. It is important to note that we picked up clones which exhibited even a very weak immunoreactivity (a borderline with non-specific signal). Therefore, a large number of primary clones were not confirmed by secondary screenings, leaving only 30 clones as true-positives. cDNA plasmids, corresponding to positive clones, were rescued by in vitro recombination approach. The size of inserts in isolated plasmids were determined by restriction analysis (data not shown). The identification of isolated clones was performed by sequence analysis followed by searching of various DNA and protein databases. The search revealed that 30 clones encode 17 genes (Table 1). Furthermore, 12 of them encode known proteins, while 5 represent so far genes with unknown functions. The sequence of isolated clones and other relevant information were submitted to the SEREX database http://www.licr.org/SEREX.html.

The analysis of SEREX database revealed that three of these genes were identified earlier by other SEREX laboratories in screens of different types of human cancer (Table 2). These include a potential transcription factor NZF, $\alpha$-catenin and a protein with unknown function BAC RP11. Noteworthy, NZF protein was isolated from libraries generated from glioma, renal cell carcinoma, ovarian and colon cancer, teratoma and normal testis. On the other hand, $a$-catenin was cloned from melanoma, renal, breast, colorectal cancer, small cell carcinoma and testis. Further analysis of other antigens identified in present study showed their relevance to malignant transformation.

For example, $\alpha$ - and $\beta$-catenins are involved in cadherin-mediated cell-cell adhesion. Disregulation of cellular functions of both $\alpha$ - and $\beta$-catenins is associated with invasive potential of malignant cells [1113]. The overexpression of ErbB-2 antigen is observed in $30 \%$ of breast cancer and is associated with poor prognosis. Moreover, ErbB2 has been also found overexpressed in thyroid and other types of human cancer $[14,15]$. In this study we have isolated the transducer of ErbB2 (clone Thy28). So far, very little is known about the function of the transducer of ErbB2. However, there is no doubt that the function of this gene in normal and transformed cells needs further investigation.

Phosphotyrosine independent ligand p62 for the Lck SH2 domain (Thy36) is a major component of intracytoplasmic hyaline bodies in hepatocellular carcinoma cells, while in non-neoplastic liver cells it was not observed [16]. p62 protein binds ubiquitin and may act as an adapter linking ubiquitinated proteins to multienzyme proteosomal complexes to other proteins. These features suggest a role for p62 in signal transduction and possibly also in carcinogenesis.

Elevated expression of proteases is observed in a variety of tumors. Clone Thy 40 encodes a protease cathepsin $\mathrm{H}$, whose expression is increased in highgrade prostatic intraepithelial neoplasia and carcinoma of the prostate [17]. Two forms of cathepsin are known: a full length and a truncated version. Both of them are enzymatically active, but truncated form has a reduced lysosomal association when compared with a full-length cathepsin $H$. It was suggested that increased expression of cathepsin $\mathrm{H}$ may affect cellular functions especially those which are associated with tumor progression and metastasis. Short-chain collagen type VIII (Thy43) was observed throughout the development of hemangioma in the study of Tan et al. [18]. It was also detected within mast cells during early proliferative phase. In several SEREX studies different ribosomal proteins have been identified as tumor-associated antigens $[19,20]$. We have identified ribosomal protein S24 (Thy32 and 35) which has not been previously detected in serological screenings by SEREX or other approaches. Several clones corresponding to non-sarcomeric myosin light chain (Thy37, 38 and 42) have been also isolated in our screen. In our previous article [8] we have reported SEREX-based detection of CDC-42 binding protein kinase. Phosphorylation of myosin light chain by $\mathrm{CDC}-42$ binding protein kinase leads to the activation of actin-myosin contractility [21]. Disregulation in actin-myosin contractility, induced by aberrant signaling may play a role in malignant invasiveness and metastatic growth [22].

The clone KY-Thy 29 encodes for the solid tumor associated protein. Two STAG1/PMEPAl mRNA transcripts of approximately 2.7 and $5 \mathrm{~kb}$, with 
RODNIN N. V. ET AL

Table 1

Immunoreactive clones isolated by SEREX screening of thyroid cancer libraries

\begin{tabular}{|c|c|c|}
\hline Group number & Clone (SEREX ID) & Homology/ldenity \\
\hline \multirow[t]{5}{*}{1} & ID: $2412, \mathrm{KY}-\mathrm{Thy} 16(2412)$ & Catenin beta-like 1 \\
\hline & ID: $2414, \mathrm{KY}-\mathrm{Thy} 18(2414)$ & \\
\hline & ID: $2417, \mathrm{KY}-\mathrm{Thy} 21(2417)$ & \\
\hline & ID: $2419, \mathrm{KY}-\mathrm{Thy} 23(2419)$ & \\
\hline & ID: 2574, KY-Thy30 (2574) & \\
\hline \multirow[t]{2}{*}{2} & ID: $2413, \mathrm{KY}-\mathrm{Thy} 17$ (2413) & $\mathrm{C} 2 \mathrm{H} 2$ zinc finger protein (NZF) \\
\hline & JD: 2418, KY-Thy22 (2418) & \\
\hline \multirow[t]{2}{*}{3} & ID: $2415, \mathrm{KY}-\mathrm{Thy} 19(2415)$ & Alpha-catenin \\
\hline & ID: $2477, \mathrm{KY}-\mathrm{Thy} 26(2477)$. & \\
\hline 4 & ID: $2420, \mathrm{KY}-\mathrm{Thy} 24(2420)$ & Homo sapiens 12 BAC RPI1-66r8 \\
\hline 5 & ID: $2476, \mathrm{KX}-\mathrm{Thy} 25$ (2476) & FXYD domain-containing ion transport regulator 3 (FXYD3) \\
\hline 6 & ID: $2478, \mathrm{KY}-\mathrm{Thy} 27$ (2478) & Homo sapiens HSPC041 protein (LOC 51125 \\
\hline 7 & ID: $2479, \mathrm{KY}-\mathrm{Thy} 28(2479)$ & Transducer of ErbB2 \\
\hline 8 & ID: $2573, \mathrm{KX}-\mathrm{Thy} 29(2573)$ & Solid tumor associated protein \\
\hline \multirow[t]{2}{*}{9} & ID: 2575, KY-Thy31 (2575) & Musashi homolog 2 (Drosophila) mRNA \\
\hline & ID: 2577, KY-Thy33 (2577) & \\
\hline \multirow[t]{2}{*}{10} & ID: $2576, \mathrm{KY}-\mathrm{Thy} 32(2576)$ & Ribosomal protein S24 (RPS24) \\
\hline & ID: 2579, KY-Thy35 (2579) & \\
\hline \multirow[t]{2}{*}{11} & ID: $2578, \mathrm{KY}-\mathrm{Thy} 34$ (2578) & Small nuclear ribonucleoprotein polypeptide $G$ \\
\hline & ID: $2583, \mathrm{KY}-\mathrm{Thy} 39$ (2583) & \\
\hline 12 & ID: $2580, \mathrm{KY}-\mathrm{Thy} 36(2580)$ & Sequestesoma 1 \\
\hline \multirow[t]{3}{*}{13} & ID: $2581, \mathrm{KY}-\mathrm{Thy} 37(2581)$ & Non-sarcomeric myosin, light polypeptide \\
\hline & ID: $2582, \mathrm{KY}-\mathrm{Thy} 38(2582)$ & \\
\hline & ID: $2586, \mathrm{KY}-\mathrm{Thy} 42(2586)$ & \\
\hline 14 & ID: $2584, \mathrm{KY}-\mathrm{Thy} 40(2584)$ & Cathepsin H (CTSH) \\
\hline 15 & ID: $2585, \mathrm{KY}-\mathrm{Thy} 41(2585)$ & Proteine phosphatase 1 , regulatory (inhibitor) subunit $15 \mathrm{~A}$ \\
\hline 16 & ID: $2587, \mathrm{KY}-\mathrm{Thy} 43$ (2587) & Collagen, type VIII, alpha 2 \\
\hline \multirow[t]{2}{*}{17} & ID: $2588, \mathrm{KY}-\mathrm{Thy} 44$ (2588) & Clone XXbac- $44 \mathrm{E} 15$ on chromosome 6 \\
\hline & ID: 2589, KY-Thy 45 (2589) & \\
\hline
\end{tabular}

identical coding regions but variant $3^{\prime}$ untranslated regions, were predominantly expressed in normal prostate tissue and at lower levels in the ovary. The expression of this gene was upregulated in $87 \%$ of RCC samples and also was upregulated in stomach and rectal adenocarcinomas.

In contrast, STAG1/PMEPAl expression was barely detectable in leukemia and lymphoma samples. Analysis of expressed sequence tag databases showed that STAG1/PMEPA1 also was expressed in pancreatic, endometrial, and prostatic adenocarcinomas. The STAG1/PMEPAl cDNA encodes a 287-amino-acid protein containing a putative transmembrane domain and motifs that suggest that it may bind src homology 3- and tryptophan domain-containing proteins. This protein shows $67 \%$ identity to the protein encoded by the chromosome 18 open reading frame 1 gene. Translation of STAG1/PMEPAl mRNA in vitro showed two products of 36 and $39 \mathrm{kDa}$, respectively, suggesting that translation may initiate at more than one site. The upregulation of this gene in several solid tumors indicated that it may play an important role in tumorigenesis [23]. The link between identified antigens and various aspects of malignant transformation, based on the literature search, is summarized in Table 3 . Our further investigations will be 
rable 2

The summary of serological properties and expression pattern of 3 genes, which were identified earlier in different SEREX screenings

\begin{tabular}{|c|c|c|c|c|}
\hline Our clone (SEREX ID) & Homology/Ideality & Group & mRNA sourse/serva & Characteristics \\
\hline KY-Thy17 (2313) & $\begin{array}{l}\mathrm{C} 2 \mathrm{H} 2 \text { zinc finger } \\
\text { protein (NZF) }\end{array}$ & University of Mainz & Testis/teratoma & Highly expressed, ubiquitous \\
\hline \multirow[t]{4}{*}{ KY-Thy22 (2418) } & & Saarland University & Testis/glioma & N/a \\
\hline & & Belozersky Institute & Renal cell carcinoma & Reacts with normal sera \\
\hline & & Belozersky Institute & Ovarian & $1 / 24$ norma, $0 / 24$ ovarian cancer \\
\hline & & LICR New York & $\begin{array}{l}\text { Testis/colon cancer metastatic } \\
\text { in lung }\end{array}$ & $\mathrm{N} / \mathrm{a}$ \\
\hline KY-Thy19 (2415) & AJpha-catenin & LICR New York & Renal cancer/renal cancer & Reacts with $1 / 19$ normal sera, \\
\hline KY-Thy26 (2477) & & & & $2 / 31$ renal cancer sera \\
\hline \multirow[t]{5}{*}{ KY-Thy 24 (2420) } & $\begin{array}{l}\text { Homo sapiens } 12 \\
\text { BAC RP11-686G8 }\end{array}$ & LICR New York & Testis/melanoma & $\mathrm{N} / \mathrm{a}$ \\
\hline & & LICR Melbourne & $\mathrm{SCC}-25 / \mathrm{rl}$ & N/a \\
\hline & & Aichi Cancer Center & Breast cancer/breast cancer & $\begin{array}{l}13 / 16 \text { breast cancer, } 11 / 15 \\
\text { normal individuals }\end{array}$ \\
\hline & & LICR New York & $\begin{array}{l}\text { Colo } 205 \text { cell line/rectal, } \\
\text { colorectal }\end{array}$ & N/a \\
\hline & & LICR Melbourne & Testis/JK & N/a \\
\hline
\end{tabular}

Table 3

A possible link between SEREX-derived antigens from human thyroid carcinoma and malignant transformation

\begin{tabular}{l|l|c|c}
\hline Group number & Ciones & Homology & $\begin{array}{c}\text { Possible role in cancer } \\
\text { development and progression }\end{array}$ \\
\hline
\end{tabular}

ID: 2412 , KY-Thyl6 (2412)

ID: $2414, \mathrm{KY}-\mathrm{Thy} 18$ (2414)

ID: 2417, KY-Thy21 (2417)

DD: 2419, KY-Thy23 (2419)

ID: 2574, KY-Thy30 (2574)

3

ID: 2415 , KY-Thy1 9 (2415)

ID: 2477, KY-Thy26 (2477)

8

ID: 2479 , KY-Thy 28 (2479)

13

ID: $2580, \mathrm{KY}-\mathrm{Thy36}$ (2580)

14

ID: $2581, \mathrm{KY}-\mathrm{Thy} 37$ (2581)

ID: $2582, \mathrm{KY}-\mathrm{Thy} 38$ (2582)

ID: $2586, \mathrm{KY}-\mathrm{Thy} 42$ (2586)

15 ID: $2584, \mathrm{KX}-\mathrm{Thy} 40$ (2584)

16 ID: 2585, KY-Thy41 (2585)

17 ID: $2587, \mathrm{KY}-\mathrm{Thy} 43$ (2587)
Catenin beta-like 1

Alpha-catenin

Transducer of ErbB2

Sequestesoma 1

Non-sarcomeric myosin, light polypeptide

Cathepsin H (CTSH)

Proteine phosphatase 1, regulatory (inhibitor) subunit 15A

Collagen, type VIII, alpha 2
The tevets of catenin expression in tumor tissue differs from the normal ones

$\alpha$-Catenin meets the criteria of an invasion suppressor gene

The expression in thyroid carcinomas correlates with the degree of aggressiveness and differentiation

Major component of intracy toplasmic hyaline bodies in hepatocellular carcinoma

Involved in invasion and metastasis of pancreatic cancer

Increased expression in high-grade prostatic intraepithelial neoplasia and carcinoma of the prostate

Involved in down-regulation of signalling pathways, inducing growth and proliferation

Short-chain collagen is localized extracellulary throughout the development of hemangioma 
focused on the elucidation of the role of identified antigens in cancerogenesis. Heterologous screenings with a panel of sera from healthy donors and patients with various types of cancer would allow us to select those which have the properties of tumor specific markers or the potential for the development of anti-cancer vaccines.

Acknowledgements. This study was supported in part by grants from the National Academy of Sciences of Ukraine, The Royal Society and INTAS. Authors are grateful to Dr. Usenko and Dr. Lyzogubov (BIONTEC, Ukraine) for providing the samples of thyroid cancer and autologous sera.

М. В. Роднін, І. О. Тихонкова, Р. Г. Кіямова, О. М. Гарифулін, I. Т. Гут, В. В. Філоненко

Ідентифікація пухлиноасоційованих антигенів папілярної карциноми щитовидної залози людини

\section{Резюме}

3 двох зразків тканини папіломи щитовидної залози людини отримано дві кДНК експресуючі бібліотеки. Јмуноскринуванням бібліотек методом SEREX ідентифіковано 30 позитивних клонів, які відповідали 17 різним генам. Потрібно відмітити, що три гени-транскрипційний фактор NZF, $\alpha$-катенін і білок BAC RPII з поки невідомою функцісюраніме виявлено в інших лабораторіях методом SEREX, де скринували бібліотеки з різних типів пухлин людини. Серед реити ідентифікованих генів найцікавішими $с$ катепсин $H$ (cathepsin H) и TOB2 (transducer of ErbB2), nidsumeny excпресію яких було знайдено в багатьох злоякісних пухлинах людини. Подальші дослідження буде направлено на виявлення частоти зустрічальності антитіл проти даних антигенів у сироватках крові хворих на рак різної етіології та здорових донорів. Серед визначених у нашій лабораторії нових SEREX позитивних клонів $\epsilon$ потенційні маркери злоякісних новоутворень цитовидної залози людини.

Н. В. Роднин, И. А. Тихонкова, Р. Г. Киямова,

О. М. Гарифулин, И. Т. Гут, В. В. Филоненко

Идентификация опухолеассоциированных антигенов

папиляярной карциномы щитовидной железы человека

Резюме

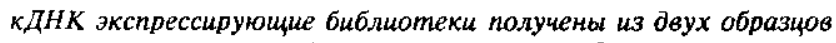
ткани злокачественной папилломы щитовидной железы человека. Иммуноскрининг библиотек методом SEREX дал возможность идентифицировать 30 положительных клонов, представляющих собой продукты 17 различных генов. Следует отметить, что три гена- транскрипционный фактор NZF, $\alpha$-катенин и белок с неизвестной функцией BAC RPII выявлены ранее в других лабораториях SEREX скринингом библиотек из различных типов опухолей человека. Среди остальных идентифицированных генов наибольший интерес представляют катепсин $H$ (cathepsin $H$ ) и TOB2 (transducer of EгbB2), повыненная әкспресия которых выявлена во многих злокачественных опухолях человека. Дальнейщие исследования будут направлены на установление частоты встречаемости антител против данных антигенов в сыворотках крови больных раком различной атиологии и здоровых доноров. Среди выявленных нами новых SEREX положительных клонов могут быть потенциальные маркеры злокачественных новообразований щитовидной железы человека.

\section{REFERENCES}

1. Schmutzler C., Koehrle J. Innovative stratcgies for the treatment of thyroid cancer // Eur. J. Endocrinol.-2000.-143.P. 15-24.

2. Shigenoby N., Nystrom E. Epidemiology and primary prevention of thyroid cancer // Thyroid.-2002.-12.-P. 889896.

3. Parmiani $G$. Tumor immunity as autoimmunity: tumor antigens include normal self proteins which stimulate anergic peripherial T cells // Immunol. Today.-1993.-14.-P. 536-538.

4. Old L. J., Chen $Y$. T. New paths in human cancer serology // J. Exp. Med.-1998-187.-P. 1163-1167.

5. Jager D., Unkelbach M., Frei C., Bert F., Scanlan M. J., Jager E., Old $L$ J., Chen Y. T., Knuth $A$. Identification of tumor-restricted antigens NY-BR-1, SCP-1, and a new cancer/testis-like antigen NW-BR-3 by serological screening of a testicular library with breast cancer serum // Cancer Immunol.-2002. $-\mathrm{N}$ 28. - P. 2-5.

6. Behrends U., Schneider I., Rossler S., Fraumknecht $H$., Golbeck A., Lechner B., Eigenstetter G., Zobywalski C., Muller-Weihrich S., Graubner U., Schmid I., Sackerer D., Spath M., Goetz C., Prantl F., Asmuss H. P., Bise K., Mautner $J$. Novel tumor antigens identified by autologous antibody screening of childhood medulloblastoma cDNA libraries // Int. J. Cancer.-2003.-106, N 2.-P. 244-251.

7. Scanlan $M$. J., Jager D. Challenges to the development of antigen-specific breast cancer vaccines // Breast Cancer Res.-2001.-3, N 2.-P. 95-98.

8. Rodnin N. V., Tykhonkova J. O., Nemazany I. O., Gorlova $L$ M., Komissarenko I. V., Palchevskiy S. S., Kuharenko O. P., Drobot L. B., Matsuka G. H., Filonenko V. V., Gout I. T. Serological identification of autoimmune reactive antigens in human thyroid cancer cells // Exp. Oncol.-2000.-22, N 3. - P. $135-138$.

9. Chomczynski P., Sacchi N. Single-step method of RNA isolation by acid guanidinium thiocyanate-phenol-chloroform extraction // Anal. Biochem.-1987.-162.-P. 156-159.

10. Rodnin M. V., Tykhonkova I. O., Filonenko V. V., Drobot $L$. B., Matsuka G. H., Gout I. T. Search and characterization of melanoma antigens with the use of serological identification of antigens by recombinant expression cloning method // Biopolymers and Cell.-2000.-16.-P. 339-345.

11. Hajra $K . M$., Fearon $E . R$. Cadherin and Catenin alterations in human cancer // Genes, Chromosmes and Cancer.2002.-34.-P. 255-268.

12. Alken E. V., Wever O. D., Correia da Rocha A. S., Mareel M. Defective E-cadherin/catenin complexes in human cancer // Virchows Arch. -2001.-439.-P, 725-751.

13. Shiozaki H., Lihara K., Oka H., Kadowaki T., Matsui S., Gofuku J., Inoue M., Nagafuchi A,, Tsukita S., Mori T. Immunohistochemical detection of alpha-catenin expression in human cancers // Amer. J. Pathol.-1994.-144, N 4.P. 667-674.

14. Soda G., Antonaci A., Bosco D., Nardoni S., Melis M. Expression of bcl-2, c-erbB-2, p53, and p21 (wafl-cip1) protein in thyroid carcinomas // J. Exp. Clin. Cancer Res.1999.-18, N 3.-P. 363-367.

15. Lee M. S., Igawa T., Yuan T. C., Zhang X. Q., Lin F. F., Lin $M$. $F$. ErbB-2 signalling is involved in regulating PSA secretion in androgen-independent human prostate cancer LNCaP C-81 cells // Oncogene.-2003.-22, N 5.-P. 781-796. 
16. Stumptner C., Heid H., Fuchsbichler A., Hauser H., Mischinger $H . J .$, Zatlokal K., Denk $H$. Analysis of intracytoplasmic hyaline bodies in hepatocelullar carcinoma // Amer. $\mathbf{J}$. Pathol.-1999.-154, N 6.-P. $1701-1710$.

17. Waghray A., Keppler D., Sloane B. F., Schuger L., Chen $Y$. $Q$. Analysis of a truncated form of cathepsin $H$ in human prostate tumor cells // J. Biol. Chem. $-2002,-277, \mathrm{~N} 13 .-$ P. $11533-11538$.

18. Tan S. T, Velickovic M., Ruger B. M., Davis P. F. Cellular and extracellular markers of hemangioma // Plast. Reconstr. Surg.-2000.-106, N 3.-P. 529-538.

19. Koroleva E. P., Lagarkova M. A., Mesheryakov A. A., Scanlan M. J., Old L. J., Nedospasov S. A., Kuprash D. V. Serological identification of antigens associated with renal cell carcinoma // Russ. J. Immunol.-2002.-7._P. 3229-3238.

20. Uemura M., Nouso K., Kobayashi Y., Tanaka H., Nakamura S., Higashi T., Ono T., Nakayama E., Hanafusa T., Shiratori $Y$. Identification of the antigens predominantly reactive with serum from patients with hepatocellular carcinoma // Cancer.-2003.-97, N 10.-P. 2474-2479.

21. Moncrieff C. L, Bailey M. E., Morrison N., Johnson K.J. Cloning and chromosomal localization of human $\mathrm{Cdc} 42$-binding protein kinase beta // Genomics.-1999.-57, N 2-P. 297300 .

22. Kaneko K., Satoh K., Masamune A., Satoh A., Shimosegawa $T$. Myosin light chain kinase inhibitors can block invasion and adhesion of human pancreatic cancer cell lines // Pancreas.2002.-24, N 1.-P. 34-41.

23. Rae F. K., Hooper J. D., Nicol D. L., Clements J. A. Characterization of a novel gene, STAG1/PMEPA1, upregulated in renal cell carcinoma and other solid tumors // Mol. Carcinog.-2001.-321.-P. 44-53.

УДК $577.29: 577.27$

Надійшла до редакції 12.02 .02 